\title{
SOFOSBUVIR: TREATMENT OF CHRONIC HEPATITIS C AND THE MAIN TRENDS IN PATENT PROTECTION
}

\section{LITVINOVA ELENA V. ${ }^{1}$, POSILKINA OLGA V. ${ }^{1}$, MASLOVA NATALIIA F. ${ }^{2}$}

${ }^{1}$ Department of Management and Economics of Enterprise, National University of Pharmacy, Kharkov, Ukraine, ${ }^{2}$ State Enterprise “State Scientific Center of Drugs", Kharkov, Ukraine

Email: maslova333gncls@gmail.com

Received: 14 Mar 2019, Revised and Accepted: 24 May 2019

\begin{abstract}
The purpose of the study was to analyze and systematize the literature data on the benefit/risk ratio of sofosbuvir administration in the treatment of patients with chronic hepatitis $\mathrm{C}$ and the main trends in its patent protection. Studies were conducted using databases on the Internet: Ukrainian patent office, the European patent office, the US patent office, the Food and drug administration, European Medicines Agency (EMEA), State enterprise "The State Expert Center" of the Ministry of Health of Ukraine. It has used retrospective, logical, systematic and analytical methods. Data from clinical studies abroad and meta-analyses indicate that sofosbuvir is one of the most promising drugs for the treatment of chronic HCV infection. Its indisputable advantages are that this drug can be used with different genotypes of the virus, decompensated liver function, it is well tolerated. Sofosbuvir has an improved safety profile and a low probability of viral resistance. The high cost of sofosbuvir is due to the powerful patent protection. As mechanisms for working with patent barriers, it is recommended to use the flexible mechanisms of the TRIPS Agreement: the grant of compulsory licenses, the implementation of parallel imports, the tightening of the criteria for patentability (prohibition of patenting new forms that do not improve therapeutic efficacy).
\end{abstract}

Keywords: Sofosbuvir, Patent, Chronic hepatitis C, TRIPS

(C) 2019 The Authors. Published by Innovare Academic Sciences Pvt Ltd. This is an open access article under the CC BY license (http://creativecommons.org/licenses/by/4.0/) DOI: http://dx.doi.org/10.22159/ijap.2019v11i4.33502

\section{INTRODUCTION}

According to World Health Organization, morbidity and mortality associated with hepatitis C virus (HCV) infection continue to increase worldwide. Each year about 700,000 people die from HCVrelated complications, including liver cirrhosis and hepatocellular carcinoma [1-6]. For Ukraine, the problem of HCV infection is really not only medically, but also socio-economically important. In Ukraine, infection with the hepatitis $\mathrm{C}$ virus of people over the age of 15 reaches $9 \%$ and up to 11,000 people die from its effects every year $[7,8]$. According to the results of selective monitoring of risk groups, the level of HCV infection among some of them is much higher than the world average rates and reaches $40-60 \%$. It should be noted that thanks to scientific breakthroughs towards the treatment of HCV infection, significant progress has been made in the treatment of this pathology and in fact, chronic hepatitis $\mathrm{C}$ has been transferred to the category of fully curable diseases.

Until recently, in Ukraine, the combination of pegylated interferon with ribavirin during 48-56 $\mathrm{w}$ was considered to be the recognized standard of therapy for this pathology. The effectiveness of this treatment was approximately $50 \%$, that is, only half of the patients undergoing therapy had a chance of cure. But, in almost all cases this therapy was a peculiar kind of trial because of side effects, namely the "flu-like syndrome", which accompanied the patient during the entire course of therapy [7].

Taking into account international recommendations, as well as proven high efficacy and favorable safety profile of direct-acting antiviral agents (DAAs) in the treatment of chronic HCV, the Unified clinical protocol on primary, secondary, tertiary care "Viral hepatitis C in adults" was updated by Order of the Ministry of Health of Ukraine dated July 18, 2016 No. 729. The HCV treatment regimens of all genotypes were revised in the updated document.

There is no doubt that effective antiviral therapy leading to the eradication of HCV infection reduces the risk of progression of hepatic and extrahepatic HCV infection manifestations, especially if the treatment is carried out before the formation of liver cirrhosis [9-17].

At least 6 genotypes and dozens of subgenotypes of HCV, the distribution of which differs in different countries of the world, are currently described. In Russia, the United States, Europe and some other countries, the most common virus is genotype 1 (HCV-1), while HCV-3 is the second most common (22-30\% of patients) [18-20].

As a result, interferon-free regimens with the use of DAAs were included in the treatment regimens of patients infected with HCV: sofosbuvir+ribavirin; sofosbuvir/ledipasvir; sofosbuvir+simeprevir; ombitasvir/paritaprevir/ritonavir and dasabuvir [21].

The purpose of the study was to analyze and systematize the literature data on the benefit/risk ratio of sofosbuvir administration in the treatment of patients with chronic hepatitis $\mathrm{C}$ and the main trends in its patent protection.

\section{MATERIALS AND METHODS}

Studies were conducted using databases on the Internet: Ukrainian patent office, the European patent office, the US patent office, the Food and drug administration, European Medicines Agency (EMEA), State enterprise "The State Expert Center" of the Ministry of Health of Ukraine. It has used retrospective, logical, systematic and analytical methods.

\section{RESULTS AND DISCUSSION}

The recommendations of the World Health Organization [22], the European Association for the Study of the Liver (EASL) [23] and the American Association for the Study of Liver Diseases (AASLD/The Infectious Diseases Society of America (IDSA), which consider current approaches to the treatment of chronic hepatitis $C$ were published. All these recommendations proposed to use regimens that include sofosbuvir as one of the main regimens of antiviral therapy for chronic hepatitis [24].

Sofosbuvir is a nucleotide pan-genotypic inhibitor of the main replicative enzyme, the RNA-dependent RNA polymerase of the NS5B region of HCV. Sofosbuvir is a prodrug that, during intracellular metabolism, is transformed into a pharmacologically active analogue of uridine triphosphate. The standard dose of sofosbuvir is one $400 \mathrm{mg}$ pill, which is taken as a single piece after a meal. After administration, sofosbuvir is rapidly absorbed. Sofosbuvir (mainly in the form of an inactive metabolite leaving hepatocytes after dephosphorylation) is characterized by an active 
secretion of the renal tubules ( $80 \%)$. Sofosbuvir can be prescribed in a full dose only for mild and moderate renal impairment, while its use is not recommended in patients with severe renal insufficiency (glomerular filtration rate $<30 \mathrm{ml} / \mathrm{min} / 1.73 \mathrm{~m}^{2}$ ) and in patients receiving treatment hemodialysis [25-27].

Although in case of moderate and severe hepatic insufficiency, the area under the concentration curve of sofosbuvir increases by $126 \%$ and $143 \%$, and the active metabolite increases by $18 \%$ and $9 \%$, respectively, nevertheless, sofosbuvir can be administered in full dose for any degree of hepatic failure.

Sofosbuvir has activity against all known HCV genotypes, has a high resistance barrier and the favorable safety profile [28]. Most adverse events observed in the clinical trials of sofosbuvir are associated with the simultaneous use of pegylated interferon and (or) ribavirin.

The efficacy and safety of sofosbuvir in patients with different HCV genotypes and various combinations of drugs were studied in large, well-designed clinical studies of the II and III phase (NEUTRINO [29], PROTON [30], ELECTRON [31], ATOMIC [32], COSMOS [33],
FUSION [34], FISSION [29], NUCLEAR [35], POSITRON [34]) and systematized by Harmeet KB et al. [36]. In clinical studies of the II phase, it was found that the most effective dose of sofosbuvir is 400 $\mathrm{mg}$ with the duration of treatment from 12 to $24 \mathrm{w}$ in various combinations with pegylated interferon and ribavirin. Similar results were obtained in numerous clinical studies of the III phase. Research results indicate a good safety profile of sofosbuvir. In its application, there was only a slight decrease in hemoglobin level and a much lower overall incidence of side effects compared with pegylated interferon-based regimens. The most frequently reported side effects were a headache, insomnia, general weakness, nausea, dizziness, pruritus, upper respiratory tract infections, skin rash, back pain, anemia grade 1 , lymphopenia grade 4 . While taking sofosbuvir, no cases of neutropenia, thrombocytopenia, or other serious side effects have been reported. In the groups of patients who received monotherapy, the only side effects that were likely to be associated with sofosbuvir were nausea and general weakness. Compared to a pegylated interferon-based regimen, tolerability of sofosbuvir monotherapy was significantly better. The data obtained indicate the efficacy and safety of sofosbuvir.

Table 1: Meta-analysis of the effectiveness and safety of sofosbuvir

\begin{tabular}{l}
\hline Study \\
\hline 1 \\
\hline Meta-analysis of six trials \\
(2346 patients; 1625 \\
treated with sofosbuvir) \\
Meta-analysis of six \\
randomized trials ( $\mathrm{n}=1427$ \\
patients) \\
Meta-analysis of 16 trials \\
(n=885 patients)
\end{tabular}

Meta-analysis of 15 studies (4230 patients) Results

2

It has not established an increased risk of cardiac outcomes, including arrhythmias (and bradycardia), among sofosbuvir-treated patients [38].

It has showed that the 12-week regimen of sofosbuvir plus velpatasvir was highly effective in HCV patients, including those with cirrhosis and former treatment experience. Except for genotype-3, adding ribavirin was not associated with significant improvements in SVR12 rates [39].

It has evaluated safety and efficacy of different combinations of direct-acting antivirals (DAAs: Sofosbuvir/ledipasvir (SOF/IDV), Paritaprevir/Ritonavir/Ombitasivir/Dasabuvir (PrOD), Daclatasvir (DCV)/Simeprevir (SMV) \pm Ribavirin (RBV) and SOF/SMV \pm RBV, Asunaprevir/Daclatavir (ASV/DCV)) in 885 liver transplant recipients with genotype 1 HCV) has carried out. It has established that DAA treatment is highly effective and well tolerated in liver transplant recipients with recurrent genotype $1 \mathrm{HCV}$ infection [40].

It has established that sofosbuvir+ribavirin for $24 \mathrm{w}$ is the most widely used and generally well-tolerated DAA therapy in Asia. However, its effectiveness is not optimal in chronic hepatitis C (Genotype 3) patients with cirrhosis [41].

Meta-analysis of 7 studies ( $\mathrm{n}=1167$ co-infected patients)

It has evaluated efficacy and safety of sofosbuvir-containing regimens in patients co-infected with chronic hepatitis $\mathrm{C}$ virus and human immunodeficiency virus. The results of this study showed that the treatment response of sofosbuvir-containing regimens in patients co-infected with HIV and HCV was satisfied. Attention should be paid to the high rates of adverse events [42].

Meta-analysis of 41 studies All oral direct-acting antiviral (daclatasvir/asunaprevir, ledipasvir/sofosbuvir \pm ribavirin) regimens treatment of HCV ( $\mathrm{n}=8574$ patients)

GT1 resulted in high cure rates in Asian patients in routine clinical practice setting including elderly patients and those with end-stage renal disease [43].

Review of data of 3311 It has established that the optimal therapeutic regimen for patients with HCV genotype 3 appears to be the patients combination sofosbuvir/daclatasvir, administered for $12 \mathrm{w}$ without the use of RBV in non-cirrhotic patients. In cirrhotics the meta-analytic approach suggests extending therapy to $24 \mathrm{w}$ [44].

The combination of sofosbuvir and ledipasvir achieved high sustained virological response rates $(>90 \%)$ in both

8 studies ( $\mathrm{n}=1892$ patients) cirrhotic and non-cirrhotic patients with HCV genotype-1. The addition of ribavirin to this regimen did not significantly increase the sustained virological response rates [45].

7 studies $(\mathrm{n}=379$ patients)

10 studies $(\mathrm{n}=2248$ Sofosbuvir+daclatasvir \pm ribavirin, regimen is of high efficacy and tolerability in liver transplant recipients with HCV infection [46].

The interferon-free regimen of sofosbuvir/ledipasvir for 12 or $24 \mathrm{w}$ with or without ribavirin is highly effective for patients) treatment of patient's withHCV genotype 1 infection [47].

\begin{tabular}{|c|c|}
\hline 1 & 2 \\
\hline $\begin{array}{l}7 \text { studies ( } n=2626 \\
\text { patients) }\end{array}$ & $\begin{array}{l}\text { Ledipasvir-sofosbuvir based therapy is a safe and effective treatment for patients with genotype } 1 \text { HCV. The addition of } \\
\text { ribavirin to ledipasvir-sofosbuvir may increase toxicity without achieving improved efficacy. Large-scale and high-quality } \\
\text { clinical research is still needed to confirm the results [48]. }\end{array}$ \\
\hline $\begin{array}{l}12 \text { studies ( } n=994 \\
\text { patients) }\end{array}$ & $\begin{array}{l}\text { Ledipasvir+sofosbuvir-based treatment is highly effective and well tolerated in liver transplant recipients with HCV } \\
\text { reinfection [49]. }\end{array}$ \\
\hline $\begin{array}{l}7 \text { studies ( } \mathrm{n}=2601 \\
\text { patients) }\end{array}$ & $\begin{array}{l}\text { The } 12 \text {-week or } 24 \text {-week sofosbuvir+ledipasvir regimen with a low incidence of adverse events is as effective and well } \\
\text { tolerated as the sofosbuvir+ledipasvir+ribavirin regimen for the treatment of patients with chronic HCV genotype } 1 \\
\text { infection [50]. }\end{array}$ \\
\hline $\begin{array}{l}9 \text { studies }(\mathrm{n}=325 \\
\text { patients) }\end{array}$ & Simeprevir+sofosbuvir \pm ribavirin is safe and effective in recipients with liver transplant with HCV-1 infection [51]. \\
\hline 27 studies $(n=3415$ & Regimens containing sofosbuvir and velpatasvir to be the best option for patients with HCV genotype 3 infections. \\
\hline patients) & Analyses indicated that ribavirin significantly increases SVR rates and should be considered if tolerated [52]. \\
\hline $\begin{array}{l}18 \text { studies ( } \mathrm{n}=2975 \\
\text { patients) }\end{array}$ & $\begin{array}{l}\text { The sofosbuvir-containing regimens in patients with HCV genotype } 2 \text { infection have better efficacy than in patients with } \\
\text { HCV genotype } 3 \text { infections [53]. }\end{array}$ \\
\hline
\end{tabular}


For further conducting pharmacokinetics studies and therapeutic drug monitoring it has developed a simple, accurate, precise, linear, rugged and rapid RP-HPLC method for quantitative estimation of sofosbuvir in human plasma [37].

Although numerous placebo-controlled studies of sofosbuvir are important evidence of its efficacy, there is a higher degree of evidence of its clinical benefits. The recognized standard of evidence-based medicine is a meta-analysis of the results of numerous studies. These sofosbuvir meta-analysis data are given in table 1.

Thus, the existing evidence base suggests that the use of sofosbuvir is effective and safe in patients in course of the treatment of viral hepatitis $\mathrm{C}$, although the risk of side effects, such as fatigue, headache and nausea, cannot be totally excluded. Their severity increases with combination therapy with interferon and other antiviral drugs [54, 55].

Table 2: Analysis of patent protection of sofosbuvir and its combinations in the USA

\begin{tabular}{|c|c|c|}
\hline Active pharmaceutical ingredient, trademark; dosage form & Patent No & Patent Expiration \\
\hline 1 & 2 & 3 \\
\hline sofosbuvir; & 7964580 & $03 / 26 / 2029$ \\
\hline SOVALDI; & 8334270 & $03 / 21 / 2028$ \\
\hline \multirow[t]{7}{*}{ Tablet; oral, $400 \mathrm{mg}$} & 8580765 & $03 / 21 / 2028$ \\
\hline & 8618076 & $12 / 11 / 2030$ \\
\hline & 8633309 & $03 / 26 / 2029$ \\
\hline & 8889159 & $03 / 26 / 2029$ \\
\hline & 9085573 & $03 / 21 / 2028$ \\
\hline & 9284342 & $09 / 13 / 2030$ \\
\hline & 9549941 & $03 / 26 / 2029$ \\
\hline ledipasvir, sofosbuvir; & 10039779 & $01 / 30 / 2034$ \\
\hline HARVONI; & 7964580 & $03 / 26 / 2029$ \\
\hline Tablet oral, & 8088368 & $05 / 12 / 2030$ \\
\hline \multirow[t]{13}{*}{$90 \mathrm{mg}, 400 \mathrm{mg}$} & 8273341 & $05 / 12 / 2030$ \\
\hline & 8334270 & $03 / 21 / 2028$ \\
\hline & 8580765 & $03 / 21 / 2028$ \\
\hline & 8618076 & $12 / 11 / 2030$ \\
\hline & 8633309 & $03 / 26 / 2029$ \\
\hline & 8735372 & $03 / 21 / 2028$ \\
\hline & 8822430 & $05 / 12 / 2030$ \\
\hline & 8841278 & $05 / 12 / 2030$ \\
\hline & 8889159 & $03 / 26 / 2029$ \\
\hline & 9085573 & $03 / 21 / 2028$ \\
\hline & 9284342 & $09 / 13 / 2030$ \\
\hline & 9393256 & $09 / 14 / 2032$ \\
\hline & 9511056 & $05 / 12 / 2030$ \\
\hline sofosbuvir, velpatasvir; & 10086011 & $01 / 30 / 2034$ \\
\hline EPCLUSA; & 7964580 & $03 / 26 / 2029$ \\
\hline Tablet; oral, & 8334270 & $03 / 21 / 2028$ \\
\hline \multirow[t]{11}{*}{$400 \mathrm{mg} ; 100 \mathrm{mg}$} & 8575135 & $11 / 16 / 2032$ \\
\hline & 8580765 & $03 / 21 / 2028$ \\
\hline & 8618076 & $12 / 11 / 2030$ \\
\hline & 8633309 & $03 / 26 / 2029$ \\
\hline & 8735372 & $03 / 21 / 2028$ \\
\hline & 8889159 & $03 / 26 / 2029$ \\
\hline & 8921341 & $11 / 16 / 2032$ \\
\hline & 8940718 & $11 / 16 / 2032$ \\
\hline & 9085573 & $03 / 21 / 2028$ \\
\hline & 9284342 & $09 / 13 / 2030$ \\
\hline & 9757406 & $01 / 30 / 2034$ \\
\hline
\end{tabular}

\begin{tabular}{|c|c|c|}
\hline 1 & 2 & 3 \\
\hline sofosbuvir, velpatasvir, voxilaprevir; & 7964580 & $03 / 26 / 2029$ \\
\hline VOSEVI; & 8334270 & $03 / 21 / 2028$ \\
\hline Tablet; oral, & 8575135 & $11 / 05 / 2033$ \\
\hline \multirow[t]{12}{*}{$400 \mathrm{mg} ; 100 \mathrm{mg} ; 100 \mathrm{mg}$} & 8580765 & $03 / 21 / 2028$ \\
\hline & 8618076 & $12 / 11 / 2030$ \\
\hline & 8633309 & $03 / 26 / 2029$ \\
\hline & 8735372 & $03 / 21 / 2028$ \\
\hline & 8889159 & $03 / 26 / 2029$ \\
\hline & 8921341 & $11 / 16 / 2032$ \\
\hline & 8940718 & $11 / 16 / 2032$ \\
\hline & 9085573 & $03 / 21 / 2028$ \\
\hline & 9284342 & $09 / 13 / 2030$ \\
\hline & 9296782 & $07 / 17 / 2034$ \\
\hline & 9585906 & $03 / 21 / 2028$ \\
\hline & 9868745 & $11 / 16 / 2032$ \\
\hline
\end{tabular}


It should be noted that sofosbuvir not only potentially provides a cure but challenges health care systems [56-63].

Access to innovative drugs and diagnostics is an important element in the control and treatment of hepatitis $\mathrm{C}$ infection. The prices requested for the new hepatitis $C$ drugs, in particular, the direct-acting antivirals as sofosbuvir, are unsustainable for most countries' health budgets. These prices may deprive thousands of patients of a curative treatment. Consequently, it remains accessible only to the most severely ill patients, in many countries these patients are with hepatic fibrosis F3A4, and early stages are not treated. Hence, this transmissible disease will continue to drive new infections.

As of 2016, a 12-week course of sofosbuvir treatment costs about US $\$ 84,000$ in the United States, US $\$ 53,000$ in the United Kingdom, US $\$ 45,000$ in Canada, and about US\$500 in India [64-66].

The high cost of sofobusfir is related to its patent protection. The analysis of sofobusfir patenting revealed its powerful patent protection (table 2). The substance is protected by several patents in many countries. The expiration of a number of patents for sofosbuvir falls on the years of 2028-2034. This allows the pharmaceutical company, Gilead Sciences INC, to have a monopoly for the sale over a long period and improve their commercial prospects.

On 15 September 2014 Gilead Sciences INC signed licensing agreements with seven Indian generic manufacturers (Cadila, Cipla, Hetero, Mylan, Ranbaxy, Sequent and Strides Arcolab), allowing these companies to manufacture sofosbuvir in India and sell it in 91 low-and-middle-income countries. Generic companies pay $7 \%$ royalties and are free to set their own prices but have to produce or buy the active pharmaceutical ingredient in India. One company was quoted with an entry price of around US\$ 300 . One nongovernmental organization expects entry prices of US\$ 400 per 12 -week course and in the medium term a reduction to around US\$ 135. Nevertheless, these generic products-which may become available within $12-18$ mo-can only be used in the 91 countries listed, and the agreement only covers four countries in Europe: Kyrgyzstan, Tajikistan, Turkmenistan and Uzbekistan. Countries that are not included can negotiate price or issue compulsory licenses to access the Indian generic versions [64].

In March, 2017 the Patent EP 2604620 (Modified fluorinated nucleoside analogues) was challenged by "European Public Health Alliance", "Doctors Without Borders", "Doctors of the World" and several more international organizations [67].

On 13 September 2018 the European Patent Office (EPO) ruled in favour of the pharmaceutical company Gilead and maintained the company's patent on hepatitis C drug sofosbuvir. The patent, however, is maintained in an amended form. Civil society involved in the case expressed dismay over the outcome and its potential effect on European drug prices.

According to report of the world community advisory board on HCV generics and diagnostics other sofosbuvir patent oppositions in the world are given in table 3 [68].

Analysis of the range of sofosbuvir and management of the intellectual property in Ukraine is given in the table 4.

The problem of viral hepatitis is common to many countries of the world, and Ukraine is no exception. For the combined interferonfree regimens recommended for the treatment of patients with different HCV genotypes and at the same time available in Ukraine are sofosbuvir+ledipasvir; paritaprevir+ombitasvir+dasabuvir+ ritonavir; ombitasvir+paritprevir+ritonavir, sofosbuvir+simeprevir.

At the same time, the recommendations of EASL 2016 allow for the use of a combination of ledipasvir+sofosbuvir in patients with HCV 1st genotype (any subtype) without cirrhosis and past treatment experience in the abbreviated regime-for an 8-week course. In 2016, when sofosbuvir was added to the treatment regimen, the frequency of achieving a sustained virological response $12 \mathrm{w}$ after the end of therapy (at least $95 \%$ of cases) was $95.2 \%$.

Table 3: Sofosbuvir patent oppositions (according to report of the world community advisory board on HCV generics and diagnostics [68])

\begin{tabular}{|c|c|c|c|c|c|}
\hline Patent opposed & $\begin{array}{l}\text { Patent international } \\
\text { publication number, title of patent }\end{array}$ & $\begin{array}{l}\text { Country or } \\
\text { region }\end{array}$ & $\begin{array}{l}\text { Opponent } \\
\text { (civil society only) }\end{array}$ & Year & Challenge status \\
\hline \multirow{6}{*}{$\begin{array}{l}\text { Sofosbuvir } \\
\text { (prodrug) }\end{array}$} & WO2008121634 & Argentina & FGEP & 2015 & Under examination \\
\hline & $\begin{array}{l}\text { "Nucleoside phosphoramidate } \\
\text { prodrugs" }\end{array}$ & China & I-MAK & 2015 & $\begin{array}{l}\text { Patent rejected in } 2015 \text {, } \\
\text { appeal pending }\end{array}$ \\
\hline & & Europe & MDM & 2015 & $\begin{array}{l}\text { Maintained in an amended } \\
\text { form; under appeal }\end{array}$ \\
\hline & & India & DNP+, I-MAK & 2013 & Under examination \\
\hline & & Russia & ITPCru & 2015 & Partially revoked (Appeal) \\
\hline & & Thailand & AAF & 2016 & Under examination \\
\hline \multirow{7}{*}{$\begin{array}{l}\text { Sofosbuvir (base } \\
\text { compound/ } \\
\text { molecule) }\end{array}$} & W02005003147 & Argentina & FGEP & 2017 & Opposition filed \\
\hline & $\begin{array}{l}\text { "Modified fluorinated nucleoside } \\
\text { analogues" }\end{array}$ & Brazil & ABIA & 2015 & $\begin{array}{l}\text { Opposition filed, preliminary } \\
\text { rejection by ANVISA, under } \\
\text { examination }\end{array}$ \\
\hline & & China & I-MAK & 2017 & Invalidation filed, case pending \\
\hline & & Europe & MDM & 2017 & Under examination \\
\hline & & Europe & MSF & 2017 & Under examination \\
\hline & & Europe & $\begin{array}{l}\text { Consortium of six } \\
\text { European NGOs }\end{array}$ & 2017 & Under examination \\
\hline & & India & DNP+, I-MAK & 2013 & $\begin{array}{l}\text { Refused first but granted later. In } \\
\text { the process of appeal }\end{array}$ \\
\hline Sofosbuvir & W02011123645 & India & DNP+, I-MAK & 2017 & Under examination \\
\hline (polymorphs) & "Nucleoside phosphorami-dates" & Ukraine & AUN of PLWH, I-MAK & 2015 & Under examination \\
\hline $\begin{array}{l}\text { Sofosbuvir } \\
\text { (process) }\end{array}$ & $\begin{array}{l}\text { W02012012465 } \\
\text { "Methods for the preparation of } \\
\text { diastereomerically pure } \\
\text { phosphoramidate prodrugs" }\end{array}$ & Ukraine & AUN of PLWH & 2016 & Rejected \\
\hline $\begin{array}{l}\text { Sofosbuvir/ } \\
\text { ledipasvir } \\
\text { (compound) }\end{array}$ & $\begin{array}{l}\text { W02013040492 A2 } \\
\text { "Methods for treating HCV" }\end{array}$ & Ukraine & AUN of PLWH & 2016 & Under examination \\
\hline
\end{tabular}


Table 4: Sofosbuvir registration and management of intellectual property in Ukraine

\begin{tabular}{|c|c|c|c|c|c|}
\hline $\begin{array}{l}\text { Period of } \\
\text { registration }\end{array}$ & Trademark & $\begin{array}{l}\text { Active pharmaceutical } \\
\text { ingredients }\end{array}$ & Manufacturer & Intellectual property & $\begin{array}{l}\text { Declared wholesale } \\
\text { prices*, US\$ }\end{array}$ \\
\hline $\begin{array}{l}31.08 .2018- \\
31.03 .2019\end{array}$ & Myhep & $\begin{array}{l}\text { sofosbuvir, } 400 \mathrm{mg} \text {, film- } \\
\text { coated tablets }\end{array}$ & $\begin{array}{l}\text { Mylan Laboratories } \\
\text { Limited, India }\end{array}$ & $\begin{array}{l}\text { Drug is manufactured under } \\
\text { license from Gilead Science } \\
\text { Ireland UC }\end{array}$ & no data available \\
\hline $\begin{array}{l}09.10 .2015- \\
09.10 .2020\end{array}$ & Sovaldi & $\begin{array}{l}\text { sofosbuvir, } 400 \mathrm{mg} \text {, film- } \\
\text { coated tablets }\end{array}$ & $\begin{array}{l}\text { Gilead Sciences, } \\
\text { Ireland UC }\end{array}$ & $\begin{array}{l}\text { Patent of Ukraine № } 110354 \\
\text { Patent of Ukraine № } 115664\end{array}$ & 15550 \\
\hline $\begin{array}{l}20.11 .2018 \\
20.11 .2025\end{array}$ & Virpas & $\begin{array}{l}\text { ledipasvir, } 90 \mathrm{mg} \text {, sofosbuvir, } \\
400 \mathrm{mg} \text {, film-coated tablets }\end{array}$ & $\begin{array}{l}\text { Strides Shasun Ltd, } \\
\text { India }\end{array}$ & $\begin{array}{l}\text { Drug is manufactured under } \\
\text { license from Gilead Science }\end{array}$ & no data available \\
\hline $\begin{array}{l}07.11 .2018- \\
07.11 .2023\end{array}$ & Sofgen & $\begin{array}{l}\text { sofosbuvir, } 400 \mathrm{mg} \text {, film- } \\
\text { coated tablets }\end{array}$ & $\begin{array}{l}\text { Hetero Labs Limited., } \\
\text { India }\end{array}$ & $\begin{array}{l}\text { Drug is manufactured under } \\
\text { license from Gilead Science }\end{array}$ & 120 \\
\hline $\begin{array}{l}07.11 .2018- \\
07.11 .2023\end{array}$ & Virso & $\begin{array}{l}\text { sofosbuvir, } 400 \mathrm{mg} \text {, film- } \\
\text { coated tablets }\end{array}$ & $\begin{array}{l}\text { Strides Shasun Ltd, } \\
\text { India }\end{array}$ & $\begin{array}{l}\text { Drug is manufactured under } \\
\text { license from Gilead Science }\end{array}$ & no data available \\
\hline $\begin{array}{l}07.11 .2018- \\
07.11 .2023\end{array}$ & Sofgen-L & $\begin{array}{l}\text { ledipasvir, } 90 \mathrm{mg} \text {, sofosbuvir, } \\
400 \mathrm{mg} \text {, film-coated tablets }\end{array}$ & $\begin{array}{l}\text { Hetero Labs Limited., } \\
\text { India }\end{array}$ & $\begin{array}{l}\text { Drug is manufactured under } \\
\text { license from Gilead Science }\end{array}$ & 220 \\
\hline $\begin{array}{l}29.03 .2017- \\
29.03 .2022\end{array}$ & Harvoni & $\begin{array}{l}\text { ledipasvir, } 90 \mathrm{mg} \text {, sofosbuvir, } \\
400 \mathrm{mg} \text {, film-coated tablets }\end{array}$ & $\begin{array}{l}\text { Gilead Sciences, } \\
\text { Ireland UC }\end{array}$ & $\begin{array}{l}\text { Patent of Ukraine № } 110354 \\
\text { Patent of Ukraine № } 115664\end{array}$ & 17314 \\
\hline $\begin{array}{l}31.10 .2018- \\
31.10 .2023\end{array}$ & Epclusa & $\begin{array}{l}\text { velpatasvir, } 100 \mathrm{mg} \text {, sofosbuir, } \\
400 \mathrm{mg} \text {, film-coated tablets }\end{array}$ & $\begin{array}{l}\text { Gilead Sciences, } \\
\text { Ireland UC. }\end{array}$ & $\begin{array}{l}\text { Patent of Ukraine № } 110354 \\
\text { Patent of Ukraine № } 115664\end{array}$ & no data available \\
\hline
\end{tabular}

*-according to https://www. apteka. ua/drugsearch?lang=en

Clinical studies carried out in Ukraine have shown that the advantages of the second generation DAAs drugs are the possibility of oral treatment with a reduction in the number of times the drug is taken, a decrease in the duration of HCV treatment (up to 8-24 w) with an improvement in the safety profile and an increase in the effectiveness of therapy $90 \%[7,69,70]$. The economic component, as well as social and political support are critical factors determining the possibility of elimination in terms of identifying the disease, its diagnosis and strategies to combat it.

In order to increase the availability of sofosbuvir for patients with hepatitis $C$ is necessary the use of the "flexible" mechanisms of the TRIPS Agreement (Agreement on trade-related aspects of intellectual property rights), namely involving the grant of compulsory licenses, the implementation of parallel imports, the tightening of the criteria for patentability etc. [71-80].

\section{CONCLUSION}

Data from clinical studies abroad and meta-analyses indicate that sofosbuvir is one of the most promising drugs for the treatment of chronic HCV infection. Its indisputable advantages are that this drug can be used with different genotypes of the virus, decompensated liver function, it is well tolerated. Sofosbuvir has an improved safety profile and a low probability of viral resistance. The drug is recommended by the World Health Organization, the European Association for the Study of the Liver (EASL) and the American Association for the Study of Liver Diseases (AASLD/the Infectious Diseases Society of America (IDSA), and also entered the Unified clinical protocol on primary, secondary, tertiary care "Viral hepatitis C in adults" of Ukraine (2016).

The high cost of sofosbuvir is due to the powerful patent protection. As mechanisms for working with patent barriers, it is recommended to use the flexible mechanisms of the TRIPS Agreement: the grant of compulsory licenses, the implementation of parallel imports, the tightening of the criteria for patentability (prohibition of patenting new forms that do not improve therapeutic efficacy).

\section{AUTHORS CONTRIBUTIONS}

All the author have contributed equally

\section{CONFLICT OF INTERESTS}

The authors declare no conflict of interest

\section{REFERENCES}

1. Lanini S, Easterbrook PJ, Zumla A, Ippolito G. Hepatitis c: global epidemiology and strategies for control. Clin Microbiol Infect 2016;22:833-8.

2. Ansaldi F, Orsi A, Sticchi L, Bruzzone B, Icardi G. Hepatitis c virus in the new era: perspectives in epidemiology, prevention, diagnostics and predictors of response to therapy. World J Gastroenterol 2014;20:9633-52.

3. Axley P, Ahmed Z, Ravi S, Singal AK. Hepatitis C virus and hepatocellular carcinoma: a narrative review. J Clin Transl Hepatol 2018;6:79-84.

4. Mohamed AA, Elbedewy TA, El-Serafy M, El-Toukhy N, Ahmed W, Ali El Din Z. Hepatitis c virus: a global view. World J Hepatol 2015;7:2676-80.

5. Dultz G, Zeuzem S. Hepatitis c virus: a European perspective. Gastroenterol Clin North Am 2015;44:807-24.

6. Millman AJ, Nelson NP, Vellozzi C. Hepatitis c: review of the epidemiology, clinical care, and continued challenges in the direct acting antiviral era. Curr Epidemiol Rep 2017;4:174-85.

7. Shelepko S. Introduction of innovative methods of treatment of viral hepatitis $C$ into clinical practice: what are the chances of a cure for infection in Ukrainian patients? Weekly Pharm 2017;1106:4-6.

8. Zaller N, Mazhnaya A, Larney S, Islam Z, Shost A, Prokhorova T, et al. Geographic variability in HIV and injection drug use in Ukraine: implications for integration and expansion of drug treatment and HIV care. Int J Drug Policy 2015;26:37-42.

9. Polamreddy P, Vishwakarma V, Gundla R. A review on anti-HCV agents targeting active site and allosteric sites of nonstructural protein 5B [NS5B]. Int J Pharm Pharm Sci 2016;8:1-18.

10. Soriano V, Vispo E, de Mendoza C, Labarga P, Fernandez Montero JV, Poveda E, et al. Hepatitis C therapy with HCV NS5B polymerase inhibitors. Expert Opin Pharmacother 2013;14:1161-70.

11. Asselah T, Marcellin P, Schinazi RF. Treatment of hepatitis C virus infection with direct-acting antiviral agents: $100 \%$ cure? Liver Int 2018;38:7-13.

12. Powdrill MH, Bernatchez JA, Gotte M. Inhibitors of the hepatitis C virus RNA-dependent RNA polymerase NS5B. Viruses 2010;2:2169-95.

13. Ayman G, Yasmine FI, Nabil ME, Mohammad AI. Direct acting anti-hepatitis $C$ virus drugs: clinical pharmacology and future direction. J Transl Int Med 2017;5:8-17.

14. Gupta V, Kumar A, Sharma P, Arora A. Newer direct-acting antivirals for hepatitis $C$ virus infection: perspectives for India. Indian J Med Res 2017;146:23-33.

15. Jhaveri M, Procaccini N, Kowdley KV. Update on hepatitis C treatment: a systematic review of clinical trials. Minerva Gastroenterol Dietol 2017;63:62-73.

16. McConachie SM, Wilhelm SM, Kale-Pradhan PB. New directacting antivirals in hepatitis $C$ therapy: a review of sofosbuvir, ledipasvir, daclatasvir, simeprevir, paritaprevir, ombitasvir and dasabuvir. Expert Rev Clin Pharmacol 2016;9:287-302.

17. Gentile I, Scotto R, Zappulo E, Buonomo AR, Pinchera B, Borgia G. Investigational direct-acting antivirals in hepatitis C treatment: the latest drugs in clinical development. Expert Opin Investig Drugs 2016;25:557-72. 
18. Cornberg M, Razavi HA, Alberti A, Bernasconi E, Buti M, Cooper C, et al. A systematic review of hepatitis C virusepidemiology in Europe, Canada and Israel. Liver Int 2011;31:30-60.

19. Smith DB, Bukh J, Kuiken C, Muerhoff AS, Rice CM, Stapleton JT, et al. Expanded classification of hepatitis C virusinto 7 genotypes and 67 subtypes: updated criteria and genotype assignment web resource. Hepatology 2014;59:318-27.

20. Messina JP, Humphreys, Flaxman A, Brown A, Cooke GS, Pybus $\mathrm{OG}$, et al. Global distribution and prevalence of hepatitis $\mathrm{C}$ virus genotypes. Hepatology 2015;61:77-87.

21. Takeda K, Noguchi R, Namisaki T, Moriya K, Akahane T, Kitade $\mathrm{M}$, et al. Efficacy and tolerability of interferon-free regimen for patients with genotype- 1 HCV infection. Exp Ther Med 2018;16:2743-50.

22. Guidelines for the care and treatment of persons diagnosed with chronic hepatitis c virus infection. Geneva: World Health Organization; 2018.

23. EASL (European association for the study of the liver) recommendations on treatment of hepatitis c 2018. J Hepatol 2018;69:461-511.

24. Lynch SM, Wu GY. Hepatitis c virus: a review of treatment guidelines, cost-effectiveness, and access to therapy. J Clin Transl Hepatol 2016;4:310-9.

25. Kayali Z, Schmidt WN. Finally sofosbuvir: an oral anti-HCV drug with wide performance capability. Pharmgenomics Pers Med 2014;7:387-98.

26. Herbst DA, Reddy KR. Sofosbuvir, a nucleotide polymerase inhibitor, for the treatment of chronic hepatitis c virus infection. Expert Opin Investig Drugs 2013;22:527-36.

27. Gentile I, Borgia F, Buonomo AR, Castaldo G, Borgia G. A novel promising therapeutic option against hepatitis $\mathrm{c}$ virus: an oral nucleotide NS5B polymerase inhibitor sofosbuvir. Curr Med Chem 2013;20:3733-42.

28. Stedman C. Sofosbuvir, a NS5B polymerase inhibitor in the treatment of hepatitis c: a review of its clinical potential. Ther Adv Gastroenterol 2014;7:131-40.

29. Lawitz E, Mangia A, Wyles D, Rodriguez Torres M, Hassanein T, Gordon SC, et al. Sofosbuvir for previously untreated chronic hepatitis c infection. N Engl J Med 2013;368:1878-87.

30. Lawitz E, Lalezari JP, Hassanein T, Kowdley KV, Poordad FF, Sheikh AM, et al. Sofosbuvir in combination with peginterferon alfa-2a and ribavirin for non-cirrhotic, treatment-naive patients with genotypes 1,2 , and 3 hepatitis $C$ infection: a randomised, double-blind, phase 2 trial. Lancet Infect Dis 2013;13:401-8.

31. Gane E, Stedman C, Hyland R, Ding X, Svarovskaia E, Symonds $\mathrm{W}$, et al. Nucleotide polymerase inhibitor sofosbuvir plus ribavirin for hepatitis C. N Engl J Med 2018;368:34-44.

32. Kowdley KV, Lawitz E, Crespo I, Hassanein T, Davis MN, DeMicco M, et al. Sofosbuvir with pegylated interferon alfa-2a and ribavirin for treatment-naive patients with hepatitis $\mathrm{c}$ genotype-1 infection (ATOMIC): an open-label, randomised, multicentre phase 2 trial. Lancet 2013;381:2100-7.

33. Lawitz E, Sulkowski MS, Ghalib R, Rodriguez Torres M, Younossi ZM, Corregidor A, et al. Simeprevir plus sofosbuvir, with or without ribavirin, to treat chronic infection with hepatitis c virus genotype 1 in non-responders to pegylated interferon and ribavirin and treatment-naive patients: the COSMOS randomised study. Lancet 2014;384:1756-65.

34. Jacobson I, Gordon S, Kowdley K, Yoshida E, Rodriguez Torres M, Sulkowski M, et al. Sofosbuvir for hepatitis c genotype 2 or 3 in patients without treatment options. $\mathrm{N}$ Engl J Med 2013;368:1867-77.

35. Lawitz EJ, Rodriguez Torres M, Denning J, Mathias A, Mo H, Gao $\mathrm{B}$, et al. All-oral therapy with nucleotide inhibitors sofosbuvir and GS-0938 for $14 \mathrm{~d}$ in treatment-naive genotype 1 hepatitis C (nuclear). J Viral Hepat 2013;20:699-707.

36. Harmeet KB, Harmanjit S, Nipunjot G, Navreet KN. Sofosbuvir: a novel treatment option for chronic hepatitis c infection. J Pharmacol Pharmacother 2014;54:278-84.

37. Madhavi S, Prameela R. Bioanalytical method development and validation for the determination of sofosbuvir from human plasma. Int J Pharm Pharm Sci 2017;9:35-41.
38. Caldeira D, Rodrigues FB, Duarte MM, Sterrantino C, Barra M, Gonçalves N, et al. Cardiac harms of sofosbuvir: systematic review and meta-analysis. Drug Saf 2018;41:77-86.

39. Ahmed H, Abushouk AI, Attia A, Gadelkarim M, Gabr M, Negida A, et al. Safety and efficacy of sofosbuvir plus velpatasvir with or without ribavirin for chronic hepatitis c virus infection: a systematic review and meta-analysis. J Infect Public Health 2018;11:156-64.

40. Liu J, Ma B, Cao W, Li M, Bramer WM, Peppelenbosch MP, et al. Direct-acting antiviral agents for liver transplant recipients with recurrent genotype 1 hepatitis c virus infection: systematic review and meta-analysis. Transpl Infect Dis 2019; e13047.

41. Wei B, Ji F, Yeo YH, Ogawa E, Stave CD, Dang S, et al. Systematic review and meta-analysis: real-world effectiveness of directacting antiviral therapies in chronic hepatitis $\mathrm{C}$ genotype 3 in Asia. Br Med J Open Gastroenterol 2018;5:e000209.

42. Li G, Zang K, Zhang G, Zhu D, Deng X. Efficacy and safety of sofosbuvir-containing regimens in patients co-infected with chronic hepatitis $\mathrm{C}$ virus and human immunodeficiency virus: a meta-analysis. Virol J 2018;15:19.

43. Ji F, Wei B, Yeo YH, Ogawa E, Zou B, Stave CD, et al. Systematic review with meta-analysis: effectiveness and tolerability of interferon-free direct-acting antiviral regimens for chronic hepatitis C genotype 1 in routine clinical practice in Asia. Aliment Pharmacol Ther 2018;47:550-62.

44. Morisco F, Granata R, Camera S, Ippolito A, Milella M, Conti F, et al. Optimization of direct anti-viral agent treatment schedule: focus on HCV genotype 3. United European Gastroenterol J 2018;6:225-37.

45. Ahmed H, Elgebaly A, Abushouk AI, Hammad AM, Attia A, Negida A. Safety and efficacy of sofosbuvir plus ledipasvir with and without ribavirin for chronic HCV genotype-1 infection: a systematic review and meta-analysis. Antivir Ther. 2017;22:369-79.

46. Liao H, Tan P, Zhu Z, Yan X, Huang J. Sofosbuvir in combination with daclatasvir in liver transplant recipients with HCV infection: a systematic review and meta-analysis. Clin Res Hepatol Gastroenterol 2017;41:262-71.

47. Rezaee Zavareh MS, Hesamizadeh K, Behnava B, Alavian SM Gholami-Fesharaki M, Sharafi H. Combination of ledipasvir and sofosbuvir for the treatment of hepatitis c virus genotype 1 infection: systematic review and meta-analysis. Ann Hepatol 2017;16:188-97.

48. Tao T, Jiang X, Chen Y, Song Y. Efficacy and safety of ledipasvir/sofosbuvir with and without ribavirin in patients with chronic hepatitis $c$ virus genotype 1 infection: a metaanalysis. Int J Infect Dis 2017;55:56-71.

49. Liao HT, Tan P, Huang JW, Yuan KF. Ledipasvir+sofosbuvir for liver transplant recipients with recurrent hepatitis c: a systematic review and meta-analysis. Transplant Proc 2017;49:1855-63.

50. He QF, Zhang QF, Zhang DZ. Efficacy and safety of ribavirin with sofosbuvir plus ledipasvir in patients with genotype 1 hepatitis C: a meta-analysis. Dig Dis Sci 2016;61:3108-17.

51. Nguyen NH, Yee BE, Chang C, Jin M, Lutchman G, Lim JK, et al. Tolerability and effectiveness of sofosbuvir and simeprevir in the post-transplant setting: systematic review and metaanalysis. Br Med J Open Gastroenterol 2016;3:e000066.

52. Berden FA, Aaldering BR, Groenewoud H, IntHout J, Kievit W, Drenth JP. Identification of the best direct-acting antiviral regimen for patients with hepatitis c virus genotype 3 infection: a systematic review and network meta-analysis. Clin Gastroenterol Hepatol 2017;15:349-59.

53. Fan $\mathrm{H}$, Huang $\mathrm{P}$, Tian $\mathrm{T}, \mathrm{Wu} \mathrm{J}$, Xia X, Feng Y, et al. Efficacy and safety of sofosbuvir-containing regimens in chronic hepatitis $\mathrm{c}$ patients with genotype 2 and 3:a comprehensive analysis of 18 randomized controlled trials. J Gastrointestin Liver Dis 2018;27:159-68.

54. Tong MJ, Chang PW, Huynh TT, Rosinski AA, Tong LT. Adverse events associated with ribavirin in sofosbuvir-based therapies for patients with chronic hepatitis c: a community practice experience. J Dig Dis 2016;17:113-21. 
55. Elbaz T, Elserafy M, Elakel W, Mohey MA, Abdo M, Hassany M, et al. Serious adverse events with sofosbuvir combined with interferon and ribavirin: real-life egyptian experience. J Interferon Cytokine Res 2017;37:348-53.

56. Steinbrook R, Redberg RF. The high price of the new hepatitis c virus drugs. JAMA Intern Med 2014;174:1172.

57. Dhingra A, Kapoor S, Alqahtani SA. Recent advances in the treatment of hepatitis c. Discov Med 2014;18:203-8.

58. van de Ven N, Fortunak J, Simmons B, Ford N, Cooke GS, Khoo S, et al. Minimum target prices for production of direct-acting antivirals and associated diagnostics to combat hepatitis c virus. Hepatology 2015;61:1174-82.

59. Chhatwal J, Kanwal F, Roberts MS, Dunn MA. Cost-effectiveness and budget impact of hepatitis C virus treatment with sofosbuvir and ledipasvir in the United States. Ann Intern Med 2015;162:397-406

60. Najafzadeh M, Andersson K, Shrank WH, Krumme AA, Matlin OS, Brennan T, et al. Cost-effectiveness of novel regimens for the treatment of hepatitis c virus. Ann Intern Med 2015;162:407-19.

61. Trooskin SB, Reynolds H, Kostman JR. Access to costly new hepatitis c drugs: medicine, money, and advocacy. Clin Infect Dis 2015;61:1825-30.

62. Iyengar S, Tay Teo K, Vogler S, Beyer P, Wiktor S, de Joncheere $\mathrm{K}$, et al. Prices, costs, and affordability of new medicines for hepatitis c in 30 countries: an economic analysis. PLoS Med 2016;13:e1002032.

63. Luhnen M, Waffenschmidt S, Gerber-Grote A, Hanke G. Health economic evaluations of sofosbuvir for treatment of chronic hepatitis c: a systematic review. Appl Health Econ Health Policy 2016;14:527-43.

64. Access to new medicines in Europe: technical review of policy initiatives and opportunities for collaboration and research Geneva: World Health Organization; 2015.

65. Umar M, Akhter TS, Akbar I, Nisar G, Osama M, Akhter TS. Role of generics in treatment of hepatitis C infection. J Ayub Med Coll Abbottabad 2016;28:890-4.

66. Heath K. Cost-effectiveness analysis of treatment timing considering the future entry of lower-cost generics for hepatitis C. Clinicoecon Outcomes Res 2018;10:539-50.

67. Stafford N. Sofosbuvir faces fresh patent challenge in Europe. Br Med J 2017;356:j1632.

68. Report of world community advisory board on HCV generics and diagnostics. Forging a path to HCV elimination: simpler tests and affordable generics. Geneva: World Hepatitis Organization; 2017

69. Zhivitsa DG, Miroshnichenko DV, Kazek VG, Petrovskaya OD, Samoilenko OV. Efficiency of lepidapasive/sopfvbulus in people who inject drugs co-infected with HIV and HCV genotype 1b. Infectious Diseases 2018;3:39-43.

70. Kolesnikova EV. Sophosbuvir in the therapy of chronic viral hepatitis c: facts and hopes. Modern Gastroenterol 2016;4:100-7.

71. Grillon C, Krishtel PR, Mellouk O, Basenko A, Freeman J, Mendão L, et al. Treatment advocate tactics to expand access to antiviral therapy for HIV and viral hepatitis C in low-to highincome settings: making sure no one is left behind. J Int AIDS Soc 2018;21:e25060.

72. Assefa Y, Hill PS, Williams OD. Access to hepatitis c virus treatment: lessons from implementation of strategies for increasing access to antiretroviral treatment. Int J Infect Dis 2018;70:65-8

73. Douglass CH, Pedrana A, Lazarus JV, 't Hoen EFM, Hammad R, Leite RB, et al. Pathways to ensure universal and affordable access to hepatitis C treatment. BMC Med 2018;16:175.

74. Correa CM. Flexibilities provided by the agreement on traderelated aspects of intellectual property rights. Bull World Health Organ 2018;96:148.

75. 't Hoen EF, Veraldi J, Toebes B, Hogerzeil HV. Medicine procurement and the use of flexibilities in the agreement on trade-related aspects of intellectual property rights, 20012016. Bull World Health Organ 2018;96:185-93

76. ' $t$ Hoen EF, Boulet P, Baker BK. Data exclusivity exceptions and compulsory licensing to promote generic medicines in the European Union: a proposal for greater coherence in European pharmaceutical legislation. J Pharm Policy Pract 2017:10:19.

77. Angeli F. With the help of a foreign ally: biopharmaceutical innovation in India after TRIPS. Health Policy Plan 2014:29:280-91.

78. Ramani SV, Urias E. Access to critical medicines: When are compulsory licenses effective in price negotiations? Soc Sci Med 2015;135:75-83.

79. Von Falck A. Compulsory licenses as a defense in pharmaceutical and biotech patent litigation. Pharm Pat Anal 2016;5:351-3.

80. Chaves GC, Oliveira MA, Hasenclever L, de Melo LM. Evolution of the international intellectual property rights system: patent protection for the pharmaceutical industry and access to medicines. Cad Saude Publica 2007;23:257-67. 